\title{
Bodas de Sinhá: processo de f(r)icção sob a máscara ritual de Dona Senhorinha
}

A casa, o corredor... No longo caminho de finas $e$ delicadas transparências, anuviada nubente. Alva, clara como a luz que alumia o caminho. Claros sons de tambores em maracatu anunciam o ritual. Olhos em luto choram a passagem na marcha compassada nupcial. É Sinhá, Dona Sinhá! Altiva, rainha de uma corte familiar. Dona, silenciosa está. Antigos odores de gaveta são também seus guias. Fátima é condutora. Nossa senhora branca, branca. Ao fim do cortejo, sob naftalina chuva, um recanto de memórias do que já foi. Mãe, avós em fotografias espalhadas. A mesa e sua branca toalha. Olhos esquivos, óculos de Santa Luzia. Num badalo... O TEMPO... Um desnudamento. Corpo rubro desleva-se. Aborto de lembranças, dos tantos filhos que encantou e se perderam em canaviais. No corpo nu em banquete, a audiência constrói a árvore de nomes passados. No chão de terra, sinhá vai gerar o novo. Vai niná-lo ao som de familiares vozes. Vozes meninas, vozes avós. Imagens meninas, imagens avós.

scrito no dia 03 de abril de 2008, o texto acima aponta, mesmo que brevemente, as camadas imagéticas pelas quais fui transpassada no processo de criação da figura de Dona Senhorinha, no espetáculo Memó-
Luciana Lyra

ria da Cana, dirigido por Newton Moreno e realizado pela Companhia Os Fofos Encenam.

Acometida por imagens das matriarcas de minha família, das sinhás das casas-grandes e dos sobrados relatadas por Gilberto Freyre, assim como da Senhorinha da dramaturgia de Nelson Rodrigues, corporifico uma figura, que por trazer forte carga memorial, procura romper com a representação, aproximando-se de um alto grau de pessoalidade. Sob a égide do que chamo aqui de máscara ritual de Sinhá, descortino um trajeto pessoal, na restauração de minha própria história como parte de uma história familiar antepassada.

$\mathrm{O}$ processo de construção de Dona Senhorinha deu-se em três fases. Por orientação da direção, a fase primeira configurou-se a partir da criação de cena não-verbal, de onde se originou a figura que chamei de noiva enlutada. Vestida de noiva, estampando grandes óculos escuros, percorria dançando um corredor de paredes transparentes ao som de uma bricolagem da marcha nupcial com o som do maracatu de corte. A cena desembocava em nudez encharcada de sangue, articulando imagens de casamento familiares à decadência da idéia do matrimônio. A cena simbolizava um luto meu quanto à idéia do casamento.

Luciana Lyra é atriz da companhia Os fofos encenam. 
Numa segunda fase, que teve como mola propulsora a oficina do professor Renato Ferracini, a noiva enlutada desdobrou-se no arquétipo da mãe extremosa. Partindo de uma fotografia pessoal, construí movimentos corporais com braços e mãos, que traziam ainda o maracatu, mas estavam num constante chamamento ao colo, um percorrer do espaço à procura do acolhimento. Uma canção de ninar constante embalava a movimentação da figura. Com a mãe extremada desenvolvi cenas verbalizadas, estabeleci contato com outros atuantes em jogos cênicos e pude ainda desdobrá-la em terceira figura: Sinhá Dona Sinhá. Proveniente de impulsos imagéticos da obra de Gilberto Freyre, Sinhá Dona Sinhá trazia à tona o poder velado da mãe, a voz dominadora e a extraordinária capacidade de ação matriarcal que se exercia na autoridade do gesto.

A terceira e última fase de construção desvelou-se, justamente, na intersecção entre a Noiva Enlutada, a Mãe Extremosa, Sinhá Dona Sinha e, enfim, a Dona Senhorinha rodrigueana. Talvez esta tenha sido a mais complexa etapa, na medida em que cenas e imagens levantadas por intermédio da memória pessoal e impulsos de jogos cênicos iam ao encontro de uma personagem de estrutura dramatúrgica pré- estabelecida. Nesta fase, os arquétipos apontados durante o processo embasaram e deram a tônica do preenchimento da personagem dramatúrgica, gerando um estado híbrido entre pessoal e ficcional.

Ao visualizar esta trajetória, percebo que o processo de atuação em Memória da Cana está calcado na ritualização das idiossincrasias dos atuantes, em detrimento da interpretação de qualquer papel. Ao vivenciar Dona Senhorinha, não me entendo personagem mas, como aponta o diretor norte-americano Richard Schechner
(2002), "não-não o personagem". Também não sou eu mesma, mas "não-não eu mesma". Entendo-me como um corpo que se multiplica na subjetividade, tornando-se ponto de passagem de diferentes estados e energias, que o atravessam sem jamais cristalizar-se num único significado ou representação. Desta maneira, nos interstícios entre eu e a persona, meu corpo adentra em constantes fluxos de memórias, revelando uma máscara ritual de mim mesma.

A experiência em Memória da Cana provoca mais do que um simples espelhamento do real. Trata-se de um processo de espelhamento interativo e matricial, diz o antropólogo Victor Turner(1982). Se como "espelhos mágicos" dramas estéticos e rituais espelham a vida, a recíproca também é verdadeira: a vida pode espelhar formas estéticas. Pessoas que se revelam como personas performatizam suas vidas.

Partindo destas proposiçóes, concluo que na atuação liminar sob a máscara ritual de $S e$ nhorinha gera-se um estado de $f(r) i c ̧ c a ̃ o$, de atrito e desconstrução que é dialeticamente inverso ao da ficção (fictio ou algo modelado, construido) (DAWSEY, 2000), que se revela na experiência da performance teatral, onde imagens do passado se articulam ao presente.

Durante a temporada de Memória da Cana, espetacularizo as matriarcas de minha família. As fotografias de minha mãe-noiva são restauradas pelo meu corpo em ação cênica, os óculos de minha avó materna são emprestados à aparente fragilidade de D. Senhorinha, as memórias ganham o centro da cena, na re-afirmação da história pessoal em diálogo direto com a história cultural. Alimento-me da máscara de Senhorinha, oferecendo a esta mesma máscara, pelo caminho inverso, a possibilidade da restauração pela experiência performática. 


\section{Referências bibliográficas}

DAWSEY, John. Victor Turner e a antropologia da experiência. São Paulo. Cadernos de Campo, 13, p. 110-21, 2005.

SCHECHNER, Richard. Performance studies - an introduction. London e New York. Routledge, 2002.

TURNER, Victor. From Ritual to Theatre. New York. PAJ, 1982. 